\title{
Stage II Thyroid Gland Medullary Carcinoma AJCC v7
}

National Cancer Institute

\section{Source}

National Cancer Institute. Stage /I Thyroid Gland Medullary Carcinoma A/CC v7. NCI

Thesaurus. Code C6134.

Stage II includes: (T2, N0, M0); (T3, N0, M0). T2: T umor more than $2 \mathrm{~cm}$ but not more than $4 \mathrm{~cm}$ in greatest dimension, limited to the thyroid gland. T3: T umor more than $4 \mathrm{~cm}$ in greatest dimension and limited to the thyroid gland, or tumor of any size with minimal extrathyroid extension (e.g., extension to sternothyroid muscle or perithyroid soft tissues). N0: No regional lymph node metastasis. M0: No distant metastasis. (AJCC 7th ed.) 